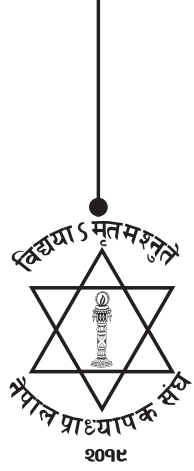

\title{
Unhomely Home: Cultural Encounter of Diaspora in Jhumpa Lahiri's The Namesake
}

\author{
Rudra Prasad Paudel \\ Lecturer, Ratna Rajya Laxmi Campus, Kathmandu \\ Email for correspondence: paudelrp@yahoo.com
}

\begin{abstract}
This article discusses unhomely home of the diasporas which is constructed geographically and psychologically by encountering the alien culture based on Jhumpa Lahiri's novel The Namesake. The purpose was to highlights recent debate on 'home' for immigrant and diasporic people. The notion of home for diasporas has become an injured concept which forces them to face scars and fractures, blisters and sores, and psychic traumas on the move. In such a situation, unhomely home refers to the condition of living here and belonging elsewhere. Jhumpa Lahiritells the story of two generations of Indian family and their struggle to acculturate themselves in the west. She presents a gloomy spectacle of racism, prejudice and marginalization in which Gogol, the son of a Bengali couple, Ashoke and Ashima Ganguli, becomes a victim of it. Gogol struggles to transform himself by escaping from the traditions of the community of Indian immigrants to which his family belongs. He also cannot assimilate with the American culture. He is an ABCD, an American Born Confused Desi. Here, Lahiri depicts that the $A B C D$ s are unable to answer the question: where are you from? This novel explores the inner psyche of characters and brings out stirring and teasing scene of identity by clash of cultures. This paper hypothesizes that neither the diasporas belong to the root nor to the foreign land. They belong to nowhere. This hypothesis is tasted with postcolonial diasporic criticism.
\end{abstract}

Key words: Home, diasporas, colonial/postcolonial literature, culture, nowhereness.

\section{Concept of 'Home' in Postcolonial Literature}

Postcolonialism analyzes and responds to the cultural legacies of colonialism and imperialism. In the past, colonialism exploited foreign lands, resources and people. During that time, the enslavement, indentured labor and migration forced many indigenous populations to move from the places that they considered home. Thus, postcolonial literature attempts to counteract their resulting alienation from their surroundings by restoring a connection between indigenous people and places through description, narration and dramatization. Postcolonial writers use detailed descriptions of indigenous people, places and practices to resist the stereotypes which the colonizers circulated in educational, legal, political and social texts and settings. Although many colonized countries are home to multiple indigenous languages, the postcolonial writers choose to write in colonizers' tongue. "Therefore, many postcolonial theorists argue that postcolonial identity is necessarily a dynamic, constantly evolving hybrid of native and colonial cultures" (Tyson, p. 422). This means that postcolonial literature emphasizes on indigenous 
culture, struggle for individual and collective cultural identity, alienation and unhomeliness, double consciousness and hybridity.

In postcolonial diasporic literature, the notion of home is unhomeliness, the feeling that one has no cultural home or sense of cultural belonging. The diasporic people perceive nostalgic links aned memories of their original home or homeland. In this regard, Stuart Hall points out, "The link between these communities and their 'homeland' or the possibility of a return to the past are much more precarious than usually thought" (p. 355). Due to modernization and globalization the diasporas themselves are deeply affected by their position, so they do not return home. The postcolonial critic Avtar Brah defines the home of diasporas in this way:

What is home? On the one hand, 'home' is a mythic place of desire in the diasporic imagination. In this sense, it is a place of return, even if it is possible to visit the geographical territory that is seen as the place of 'origin'. On the other hand, home is also a lived experience of a locality. Its sounds and smells, its heat and dust, balmy summer evenings, somber grey skies in the middle of the day, all this, as mediated by the historically specific of everyday social relations. In other words, the varying experience of pains and pleasures, the terrors and contentments or the highs and humdrum of everyday lived culture that marks how, for example, a cold winter night might be difficultly experienced sitting by a crackling fireside in a mansion compared with standing huddled around a makeshift fire on the streets of nineteenth century England (p. 192).

This expression demonstrates that the notion of home for diasporas is much more complex and ambivalence. The home of origin and the home of settlement juxtapose, and the diasporic identity can often draw much more on the experience of migrancy and settlement of making one's home than on a fixation to a homeland.

Similarly, for Salman Rushdie, the idea of home has been a damaged concept as he says in his book East, West, "Home has become such a scattered, damaged, various concept in our present travails" (p. 93). For Rushdie, home signals a shift away from homogeneous nation-states based on the ideology of assimilation to a much more fluid and contradictory definition of nations as a multiplicity of diasporic identities. On of the overriding characteristics of diasporas is that they do not, as a general rule, return. They are at the threshold. Thus, they are hunted by some sense of loss, rootlessness and alienation.

Unhomely is not homelessness. It means to feel no at home even if one is in one's own home. For the diasporic people, the sense of belonging to the family and the nation is ruptured. They leave the space called home or homeland and reconstruct home by moving beyond boundaries, and the "home is no longer just one place. It is locations" (Location, Bhabha p. 57). This position is echoed in Jhumpa Lahiri's The Namesake in which she constructs home in the luminal space between the two countries and two cultures because the Ganguli children in the novel are transnational. Transnationalism postulates multiple allegiances, affinities, emotional attachments, solidarities, obligations, identities and sense of belonging which span international borders. Mrs Ganguli in The Namesake is appropriately named Ashima which means without borders, "True to the meaning of her name, she will be without borders, without home of her own, a resident everywhere and nowhere" (Lahiri, p. 276). It means that she is transnational citizen who does not have a fixed home. 
As a postcolonial novel, Lahiri's The Namesake spins the story of a Bengali couple and their wards' voyage between two continents and cultures. The novel depicts a postcolonial world where the story covers the events from 1968-2000. After their arranged marriage, the Bengali couple Ashoke and Ashima moves to Cambridge from their ancestral homeland, Kolkata. Ashoke, a doctoral candidate of electrical engineering at Massachusetts Institute of Technology (MIT), willingly immigrates to America in search of better opportunities for him and his family. So, he easily adapts to the mores of the American society. However, Ashima's immigration defies her self-will. She simply follows in the footsteps of her better-half. In the initial part of the novel, Ashima's unwillingness to migrate and settle in an alien milieu causes her much pain. As a newly wed-bride, she pines for her lost home, and desperately wishes to go back. She misses her family in the wake of her loneliness. She sobs, complains and moans for her home, but finds none to console herself. She is nostalgic and often fancies an imaginary homeland. She reads the same five Bengali novels that she owns several times, yet she is unable to throw them away. She rejoices rereading the letters from back home written in Bengali hand and keeps them preserved.

Ashoke and Ashima spend three decades of their lives in America. They try to naturalize themselves as American citizens. They hold an American passport, a driving license and a social security card. Officially they can claim the house at 67 Pemberton Road as their own. However, they never fully feel 'at home' in America. Rather they take themselves as permanent foreigners and wish to return to India someday. Moreover, they make occasional family trips to India throughout their lives. Thus, they are portrayed as transnational beings who keep on moving back and forth. After Ashoke's death, Ashima acts as per her name i.e. without borders. She decides to spend her time between India and America. Meanwhile, Gogol is plagued by an acute sense of homelessness. He has inherited as a sense of exile from his parents. He can neither claim America nor India as his homeland. His Bengali heritage forbids him from completely assimilating into the white American society. On the other hand, the clan of his relatives in Kolkata is not enough for him to consider India as his homeland. Hence, the postcolonial diasporic literature raises question regarding the definition of 'home' and the diasporic people wage a constant psychic battle: the original home is replete with myth and tradition; the new home is proliferate with thirst for freedom and independence. They are in a dilemma as to whether they should remain in a ghetto of old values with least interaction with the majority, or break the barriers and get assimilated with the overwhelming new culture.

\section{Diaspora, Diasporic Writing and its Major Issues}

Literally, 'diaspora' refers to immigrants, guest-workers, ethnic and racial minorities, refugees, expatriates and travelers. This term is originated from Greek word that stands for 'scattering' or 'dispersion' or 'sowing of seeds'. In this sense, N. Jayaram discusses about the origin of the term as, "Etymologically, the term diaspora is derived from the Greek composite verb dia- and speirein (infinitive), literally meaning 'to scatter', 'to spread' or 'to disperse"” (p. 16). Similarly, the word 'diaspora' was commonly used to refer to the physical dispersion of Jews from Israel following the Babylonian conquest as the Dictionary of Human Geography defines "A scattering of people over SPACE and transnational connections between people and places. The term was first used to describe the forced dispersal of the Jews from Palestine in the sixth century BCC, and often continues to refer to forced MIGRATION and exile" (Gregory, p. 158). Despite its Greek root, the term 'diaspora' began 
to gain prominence only after the era of European colonialism. For Bill Ashcroft, Gareth Griffiths and Helen Tiffin, diaspora cannot be separated from colonialism; it was colonialism that led to the displacement of people across the world under different circumstances. They say, "Under colonialism, diaspora is a multifarious movement involving the temporary or permanent movement of Europeans all over the world leading to colonial settlement" (p. 68).

In the present context, the term 'diaspora' stands for the transnational mass of people, especially cultural minorities, with common roots who have migrated and settled away from their ancestral homelands. These people might have scattered for varied purposes, voluntarily or unwillingly, but they still cherish a dream to move back to their homelands at some point. They have immense attachment to the nation of origin and identification that might be remembered, imagined, or lost. Therefore, a person who belongs to the diasporic community is someone living away from his native place of origin. Nevertheless, he//she still harbors fond memories of his/her birthplace, which he/she considers as his/ her true homeland.

Diasporic writing, within a variety of academic disciplines, is a postcolonial body of writing that involves an idea of a forsaken homeland. The people who belong to diasporic community might have crossed over geographical boundaries, but they are still bound to their natal territories by cultural ties. Many diasporic people share an ambivalence relationship with their host country and their homeland. The homeland is often remembered with fondness while the host country is often seen as alienating. But eventually, the host country becomes home in a way. They assimilate and observe some aspects of host culture into their native culture and thus bring forth a unique culture. Hence, diasporic writing is hybridized product. Indeed, the diasporic writers are urged to look back and reclaim their original homeland, but they can recreate only fictional version of this homeland in their writings. The write-ups in a way compensate the loss for them as Salman Rushdie in his Imaginary Homelands maintains, "It may be that writers in my position, exiles or emigrants or expatriates, are hunted by some sense of lose, some urge to reclaim, to look back even at the risk of being mutated into the pillars of salt, that we will in short create fiction, not actual cities or villages but invisible ones imaginary homeland, Indians of the mind" (p. 10). Rushdie further describes his journey for a photograph of his ancestral home to the concrete structure of that home in Bombay. The photograph remains him that "it's my present that is foreign, and that the past is home, albeit a lost home in a lost city in a mists of lost time" (p. 9). Here, he is unable to relate to his present in a way he can relate to his past for it is his past that has shaped his identity in the present context. As a result, for him, his present is 'foreign' while his past is 'home'. In this way, the diasporic writing is full of nostalgic experiences feeling of dislocation, rootlessness and alienation, sense of isolation, identity crisis and cultural ambivalence. The diasporic writers like Jhumpa Lahiri mirror these major diasporic issues in their writings.

\section{Unhomely Home: Cultural Encounters of Diaspora in The Namesake}

Jhumpa Lahiri's The Namesake demonstrates the fascinating accounts of the diasporic experience. Moving between events in Kolkata, Boston and New York, the novel examines the nuances involved with being caught between two conflicting cultures with their highly distinct religious, social and ideological differences. This novel tells us about the adjustment problems of Indians, both first and second generations, who have now settled in America. The tension between adhering to Indian culture and imbibing American culture, between upholding family tradition and subscribing to the individual 
freedom and realization that one is an outsider even though one is born there is beautifully highlighted in the novel.

Lahiri's The Namesake opens with Ashima recalling her homeland fondly. She is in an advanced stage of pregnancy, admitted in a hospital for her delivery, "But nothing feels normal to Ashima, nothing has felt normal at all. It's not so much the pain, which she knows somehow, she will survive. It's the consequence: motherhood in a foreign land. It was happening so far from home, unmonitored and unobserved by those she loved" (Lahiri, pp. 5-6). When the Ganguli couple moves to the US and settles in Cambridge and Massachusetts, they encounter and face new culture. An engineer working at Massachusetts Institute of Technology, Ashoke adapts more quickly to life in America in contrast to his wife Ahima who resists all things American and pines for her family in Kolkata. When a son is born to Gangulis, they are faced with the realization that they cannot wait for a suitable name for the child. Ashoke names the boy Gogol after a Russian writer Nikolai Gogol whose book he credits with saving his life. But Gogol who does not know the reason for giving him this name is unable to identify either with the Americans or with the Indians. The Ganguli family cannot think "Pemberton Road as home" (p. 108) though they have a large circle of Bengali migrants as their friends. Gogol and Sonia, American born and educated children, want to be accepted as Americans but they feel alienated both from their parents and from their American friends who consider them as outsiders. The idea of 'home' is central to all human beings in every culture. Having stamped the pleasures and pains of the world, one longs to return to one's home. Home is a transnational space in Lahiri's fiction. According to Bhabha, "In the stirrings of the unhomely, another world becomes visible the does not remain the domain of domestic life, not does the world simply become its social or historical counterpart. The unhomely is a shock of recognition of the world-in-the-home, the home-in-the-world" (The Home, p. 141). In The Namesake, Ashima's unhomeliness - her ability to negotiate the world in her home and ultimately be at home in the world - conflicts the domestic space with her transnationality and her ability to navigate between cultures.

Moreover, the displacement also gives rise to the concept of double consciousness and unhomeliness which are the two features of postcolonial diasporic identity. It is apt to quote Lois Tyson who analyzes this concept thus, "Double consciousness often produced an unstable sense of self, which was heightened by the forced migration colonialism frequently caused. Being 'unhomed' is not the same as being homeless. To be unhomed is to feel not at home even in your own home because you are not at home in yourself: your cultural identity crisis has made you a psychological refugee, so to speak" (p. 421). Thus diasporic identity is plural and is always in flux.

Lahiri's first generation characters Ashoke and Ashima are rooted in Bengali culture. Ashima is a distinctive Bengali woman who never addresses her husband by his name. She tries to follow all Bengali ceremonies for her children, Gogol and Sonia, so that she can inculcate Indian values in them. To learn their children Bengali culture, they most often attend Bengali social gatherings along with them. Here, Lahiri shows how Ashima upholds her Indian culture living in modernized American society. In the novel, cultural conflict arises because the parents of Gogol intend to grow their children in Indian culture; however, their children prefer to follow American culture. Going to Kolkata is a joy for them but the two children have no attachment to either India or their relatives. Gogol and his sister Sonia love Christmas more than Durga Puja and find Bengali cultural lesions boring. For their parents, 
India is their desh (country) but "Gogol never thinks of India as desh. He thinks of it as Americanas do, as India" (Lahiri, p. 118). Like every American kid, Gogol ultimately moves away from home. He does not hate his parents but the things they say do not interest him.

Throughout the novel, Gogol is pained by his name. He feels uncomfortable with his identity. When he renames himself Nikhil, he assumes the existence he admires and moves away from his Bengali heritage. Gogol keeps on running away from his culture. He falls in love with a white girl named Maxine and enjoys the company of her parents but feels ashamed of his own parents because they do not fit into American culture. From the beginning of his life, Gogol has been rebellious. He changes his name from Gogol to Nikhil which is in fact manifestation of his protest. In acts of disobedience, he loses his virginity at a party having a short affair with a white girl Ruth. Later, he has a more durable affair with Maxine, another well to do white girl but he has been drawn toward his origin when he becomes "conscious of the fact that his immersion in Maxine's family is betrayed of his own" (p. 141). The drastic change comes in his life when he gets the news of his father's death. His father's sudden death affects him deeply as he learns to connect with him and hi past. He breaks off the relationship with Maxine and begins to spend more time with his mother and sister.

As Gogol slowly realizes the importance of his family and his culture, he marries Moushumi, a Bengali girl in Indian tradition, with all their rituals. But Moushumi, as a quite and shy young teen tastes freedom in her twenties, the freedom from her parents and their strict Bengali ways, "With no hesitation, she had allowed men to seduce her in cafes, in parks, while she gazed at paintings in museums. She allowed the men to buy her drinks, dinners. There were days she slept with one man after lunch, another after dinner" (p. 215). Since then Moushumi and Gogol divorce because "they have not considered it their duty to stay married, as the Bengalis of Ashoke and Ashima's generation do" (p. 276). On the other side, Sonia is preparing to marry an American man named Ben. Finally, the widowed Ashima sells her home in America and decides to divide her time between the United States, where she will stay with her children, and Kolkata, where she will stay with other family members with an American passport, driving license and social security card in her bag. This rootless existence demonstrates that neither the US nor India can claim her; however she claims both as her own. Yet, the answer of the question 'which home is she responsible?' is unanswered. Something inside of Gogol changes when he becomes once again alone. He feels that 'home' comforts him. By the end of the novel, Gogol has come to accept his name which holds hi family history. He picks ups a collection so Nikolai Gogol's stories that his father had given him as a birthday present many years ago. He begins to assume his family's history as a series of accidents, from his father's train crash to his doomed marriage. The novel ends with Gogol thinking that he is now free to do what pleases him. He neither can accept American culture nor return to India. Thus, The Namesake as a representative postcolonial diasporic novel exhibits the everlasting dilemma faced by the South Asian diasporas in the First World. The encounter of antagonistic cultures in diasporas makes them psychological refugees and they feel torn between two homes which neither they belong.

\section{Conclusion: Diaspora in Nowhereness}

The diasporas' condition of living here and belonging elsewhere refers to unhomeliness in Lahiri's The Namesake in which the Indian immigrants and ABCDs in the United States can easily feel a sense of living in exile, loss of communication, the sense of belonging to nowhere, inability to feel 
accepted and complicated social status. Dealing with the themes of immigrant experience, identities and displacement, and ties and clashes between the generations, this novel question: which home do the diaspora belong and take responsibility culturally and geographically? The novel focuses on the nowhereness of the characters. The Ganguli children realize that neither they are Americans nor Indians. Gogol cannot erase his past so he accepts his name and his parents' home. Likewise, he cannot disregard the present American home in which he brings up. That's why, his responsibility whether for the past or the present remains confused. Therefore, he is in nowhereness. In the same way, after the death of Ashoke, Ashima wants her children to do well and good jobs in America. Though she follows the Indian moral and cultural code at home, the American dream looms in her eyes and she wants her children to exploit the situation and derive the maximum benefits from this dreamland. So, in spite of selling her house on Pemberton Road in the US, she decides to spend six months in India and six months in the US. By this, we understand that as an Indian diaspora, she is neither responsible for Indian home nor American home. She is without a home of her own, a resident of nowhereness. In short, the residents of nowhereness, i.e. the diasporas, are always in transit, neither in nor out. They live in the tragic nowhereness and consciousness. The more they are conscious, the deeper feeling of tension, stress and tragedy they acquire like the Lahiri's representative characters, Gogol and Ashima in The Namesake. The encounter, confrontation or tension between the desire for assimilation in the free American world and the need for ethnic identity lead the diasporas in the space of nowhereness.

\section{References}

- - -. The Location of Culture. London: Routledge, 1994.

- - -. Imaginary Homelands: Essays and Criticism 1981-1991. London: Penguin Books, 1992.

Bhabha, H. K. (1992). "The Home and the World.” The Social Text, 31(32), 141-153.

Bill, A., Griffiths, G. \&Tiffin, H. (1998). Key Concepts in Post-colonial Studies. London and New York: Routledge.

Brah, A. (1996). Cartographies of Diaspora: Contesting Identities. London: Routledge Publication.

J. Derek et al., (Eds). (2009). Dictionary of Human Geography (5th ed.). London: Blackwell Publication.

Jayaram, N. (Ed.). (2004). "Introduction: The Studies of Indian Diaspora." The Indian Diaspora: Dynamics of Migration (pp.10-19). New Delhi: Sage Publication.

Lahiri, J. (2010). The Namesake. London: Harper Collins Publishers.

Rushdie, S. (19943). East, West. London: Jonathan Cape Publication.

Stuart, H. (1993). “Culture, Community, Nation.” Cultural Studies, 349-63. London: Sage Publication.

Tyson, L. (2010). Critical Theory Today: A User-Friendly Guide. New York: Routledge Publication. 